\title{
Thyroid Hormone Modulation of the Hypothalamic Growth Hormone (GH)-releasing Factor-Pituitary GH Axis in the Rat
}

Nobuhiro Miki, Masami Ono, Naomi Hizuka, Tomoko Aoki, and Hiroshi Demura

Department of Medicine, Institute of Clinical Endocrinology, Tokyo Women's Medical College, Tokyo 162, Japan

\begin{abstract}
Both thyroid hormone and hypothalamic growth hormone (GH)-releasing factor (GRF) facilitate pituitary somatotroph function. However, the pathophysiological role of thyroid hormone in GRF secretion is less well understood. Thyrotoxicosis, induced by administration of thyroxine $\left(T_{4}\right)$ in rats, inhibited both pituitary GH levels and immunoreactive GRF secretion from incubated hypothalamus. At the highest dose of $\mathrm{T}_{4}$ given for $12 \mathrm{~d}$, GRF secretion and pituitary GH decreased by $\mathbf{5 0}$ and $39 \%$, respectively. Hypothyroidism induced by thyroidectomy ( $T_{x}$ ) enhanced GRF secretion approximately twofold while depleting pituitary GH by $>99 \%$. Both of these hypothalamic and pituitary effects were reversed by replacement of $T_{4}$ but not human GH for 7 or 14 d. Human GH was as potent as $T_{4}$ in restoring decreased body weight gains or serum insulin-like growth factor-1 levels in $T_{x}$ rats. These results indicate that at both physiological and pathological concentrations in serum, thyroid hormone acts as an inhibitory modulator of GRF secretion, probably not involving a feedback mechanism through GH. A biphasic effect of thyroid hormone on pituitary GH levels appears to derive from the difference in primary target tissues of hyper- and hypothyroidism, the hypothalamus and the pituitary, respectively. (J. Clin. Invest. 1992. 90:113-120.) Key words: hyperthyroidism • hypothyroidism - somatotropin • somatotropin-releasing factor $\bullet$ insulin-like growth factor-I
\end{abstract}

\section{Introduction}

Secretion of pituitary growth hormone $(\mathrm{GH})^{1}$ is positively regulated by the hypothalamic peptide, GH-releasing factor (GRF) (1-3). GRF generates spontaneous bursts of GH secretion (46 ) and also increases $\mathrm{GH}$ gene transcription and GH mRNA levels $(7,8)$. Somatostatin (SRIF) is the hypothalamic peptide

Portions of this work were presented in abstract form at the 1st International Congress of Neuroendocrinology, San Francisco, CA, 9-11 July 1986, and at the 8th International Congress of Endocrinology, Kyoto, Japan, 17-23 July 1988.

Address reprint requests to N. Miki, Department of Medicine, Institute of Clinical Endocrinology, Tokyo Women's Medical College, 8-1 Kawada-cho, Shinjuku-ku, Tokyo 162, Japan.

Received for publication 23 September 1991 and in final form 31 January 1992.

1. Abbreviations used in this paper: $\mathrm{BW}$, body weight; $\mathrm{GH}$, growth hormone; GRF, GH-releasing factor; hGH, human GH; HKRB, Hepes-buffered Krebs-Ringer bicarbonate solution; IGF-I, insulin-like growth factor-I; SRIF, somatostatin; $\mathrm{T}_{3}$, triiodothyronine; $\mathrm{T}_{4}$, thyroxine; $\mathrm{T}_{\mathrm{x}}$, thyroidectomy or thyroidectomized.

J. Clin. Invest.

(c) The American Society for Clinical Investigation, Inc. 0021-9738/92/07/0113/08 \$2.00

Volume 90 , July $1992,113-120$ that inhibits GH secretion $(9,10)$ and may be also involved in the regulation of GRF secretion within the hypothalamus (11, 12). Although GRF and SRIF play a primary role in GH secretion, there are other important hormones that modulate pituitary GH secretion, probably through effects on the GH-regulatory peptides, GRF and/or SRIF. These include thyroid hormone, adrenal glucocorticoid, and gonadal steroid of peripheral endocrine organs (13). The most important for growth and development of mammals is thyroid hormone. Thyroid hormone stimulates synthesis and secretion of GH (14-16) and also increases GH gene transcription and GH mRNA levels (17-19). Hypothyroidism depletes pituitary GH (14-16), inhibits GH secretion (20-22), and causes severe growth retardation (23).

Thus, both thyroid hormone and GRF directly stimulate pituitary somatotroph function, and their hypophyseal actions are similar in many aspects. However, the pathophysiological role of thyroid hormone in hypothalamic GRF secretion is less well understood. It appears more complex because GRF receives a negative feedback signal from GH (24-27), so thyroid hormone might influence GRF secretion indirectly through the effect on pituitary GH. Furthermore, thyroid hormone has a biphasic effect on growth rate. In immature animals and young patients, growth is retarded by hypothyroidism, is restored by replacement doses of thyroxine $\left(\mathrm{T}_{4}\right)$, and is inhibited by thyrotoxic doses of $T_{4}(28)$. We and others previously reported that thyroidectomy $\left(T_{x}\right)$ enhanced in vitro secretion of hypothalamic GRF in rats $(26,29)$. Whether this effect is caused by thyroid hormone deficiency per se or mediated through associated GH deficiency remains unknown. Also unknown is the effect of hyperthyroidism on GRF secretion.

In the present studies in rats, we have compared effects of thyroid hormone excess and deficiency in vivo on hypothalamic GRF secretion in vitro. To examine the mechanism of action of hypothyroidism, we have investigated whether the $T_{x}$-induced rise in GRF secretion is reversible by replacement of $T_{4}$ or human $\mathrm{GH}(\mathrm{hGH})$. We have also studied effect of hGH in combination with $T_{4}$, because $\mathrm{GH}$ given with $\mathrm{T}_{4}$ promotes the growth of thyroid-deficient animals more than $\mathrm{GH}$ alone $(23,30)$. In experiments with $\mathrm{hGH}$, serum levels of insulin-like growth factor-I (IGF-I) as well as body weight gains were measured as an index of a biological effect of hGH. Finally, we have characterized GRF secreted in the medium to examine whether an abnormal thyroid status alters a molecular form of GRF.

\section{Methods}

\section{Chemicals}

Sodium L-thyroxine $\left(\mathrm{T}_{4}\right)$ was obtained from Sigma Chemical Co. (St. Louis, MO). Recombinant hGH was provided by Sumitomo Pharmaceutical Co. Ltd. (Osaka, Japan). Acetonitrile $\left(\mathrm{CH}_{3} \mathrm{CN}\right)$ and 2-propanol were obtained from Kanto Chemical Co. Ltd. (Tokyo, Japan) 
and trifluoroacetic acid (TFA) from Wako Pure Chemical Industries Ltd. (Osaka, Japan). Synthetic rat GRF was purchased from Peninsula Laboratories, Inc. (Belmont, CA).

\section{Animals and experimental protocols}

Male Sprague-Dawley rats were obtained from Japan SLC Inc. (Hamamatsu City, Shizouka, Japan) at 5 wk of age. They were housed in a room under controlled temperature $\left(22 \pm 1^{\circ} \mathrm{C}\right)$, humidity $(50-55 \%)$ and light/dark conditions (lights on 0800-2000 h). Food and water were available ad libitum.

Hyperthyroidism was induced at 10-11 wk of age by subcutaneously injecting $T_{4}$ once daily for 6 or $12 \mathrm{~d}$. Animals were weighed daily at $1700-1730 \mathrm{~h}$, and $\mathrm{T}_{4}$ was given on a daily weight basis in doses of 25 , 50 , or $100 \mu \mathrm{g} / 100 \mathrm{~g}$ body weight (BW). An intermediate $50 \mu \mathrm{g} / 100 \mathrm{~g}$ $B W$ dose of $T_{4}$ was the dose that inhibited BW gain but did not reduce pretreatment $\mathrm{BW}$, according to the results of a preliminary experiment. $\mathrm{T}_{4}$ was dissolved in $50 \%$ propyleneglycol and diluted four times with $0.0033 \mathrm{~N} \mathrm{NaOH}$ before subcutaneous administration. Control rats received vehicle injection. The animals were killed by decapitation $20 \mathrm{~h}$ after the last injection. Hypothalamic tissues were obtained for subsequent incubation experiments and anterior pituitaries for $\mathrm{GH}$ measurement. The trunk blood was also collected in experiments in which $\mathrm{T}_{4}$ or vehicle was administered for $12 \mathrm{~d}$.

Hypothyroidism was produced by surgical thyroidectomy $\left(T_{x}\right)$ at 6 wk of age. Because parathyroidectomy attenuates pulsatile GH secretion in rats (31), at least three parathyroid glands were left, and calcium was not supplemented in drinking water. From 4 wk after operation, $T_{x}$ rats were replaced once daily with a "physiological" dose of $T_{4}$ ( 1 or $2 \mu \mathrm{g} / 100 \mathrm{~g} \mathrm{BW}$ ) or treated twice daily with hGH $(100 \mu \mathrm{g} / \mathrm{rat}$ ) for $7 \mathrm{~d}$. hGH was dissolved in physiological saline. In the next experiments, $T_{x}$ rats received the same treatments for $14 \mathrm{~d}$. Finally, we investigated whether hGH could affect GRF secretion synergistically with thyroid hormone. $T_{x}$ rats were supplemented with $T_{4}$ alone $(2 \mu \mathrm{g} / 100$ $\mathrm{g} \mathrm{BW}$, once daily) or in combination with $\mathrm{hGH}(100 \mu \mathrm{g} / \mathrm{rat}$, twice daily) for $7 \mathrm{~d}$. $\mathrm{T}_{4}$ was injected subcutaneously at $1730-1800 \mathrm{~h}$ and $\mathrm{hGH}$ at $0830-0900 \mathrm{~h}$ and $1730-1800 \mathrm{~h}$. Control $\mathrm{T}_{\mathrm{x}}$ and sham-operated rats were treated with vehicles for $\mathrm{T}_{4}, \mathrm{hGH}$, or both. The animals were decapitated $18 \mathrm{~h}$ after the last injection; and the hypothalamus, anterior pituitary, and trunk blood were collected.

\section{Hypothalamic incubation}

The method of hypothalamic incubation has been described elsewhere (24). In brief, the brain was obtained after cutting the pituitary stalks carefully, and the hypothalami were cut sagittally through the median eminence with the ventral surface up. The area between the posterior border of the optic chiasma, the anterior border of the mammillary body, the lateral hypothalamic sulcus, and $2 \mathrm{~mm}$ deep from the ventral surface was dissected into two fragments. The fragments were placed in polyethylene vials containing $0.6 \mathrm{ml}$ of $11 \mathrm{mM}$ Hepes-buffered KrebsRinger bicarbonate solution (HKRB), pH 7.40, which was pregassed with $95 \% \mathrm{O}_{2}-5 \% \mathrm{CO}_{2}$ and supplemented with $5.5 \mathrm{mM}$ glucose, $0.1 \%$ BSA, and $500 \mathrm{mg} / \mathrm{ml}$ bacitracin. Four hypothalamic fragments from two rats were incubated in one vial. All incubations were $30 \mathrm{~min}$ at $37^{\circ} \mathrm{C}$ under an atmosphere of $95 \% \mathrm{O}_{2}-5 \% \mathrm{CO}_{2}$ in a shaking water bath $(60 \mathrm{cycles} / \mathrm{min})$. After preincubation, the tissues were incubated in HKRB (basal secretion) and then in $50 \mathrm{mM} \mathrm{K}^{+}$-containing HKRB $\left(\mathrm{K}^{+}\right.$-stimulated secretion). The medium was collected every $30 \mathrm{~min}$ and replaced with fresh buffer. The collected medium was centrifuged at $3,000 \mathrm{rpm}$ for $5 \mathrm{~min}$ at $4^{\circ} \mathrm{C}$, and the supernatants were quickly frozen on dry ice and kept at $-20^{\circ} \mathrm{C}$ until assayed. Each hypothalamic incubation used 18-24 animals, and a secretion experiment consisted of two to three separate incubations.

\section{Tissue extraction}

Immediately after the hypothalamic incubations, four hypothalamic fragments were pooled and GRF in the tissues was extracted as described (24). The fragments were boiled for $7 \mathrm{~min}$ and homogenized by polytron in $1 \mathrm{~N}$ acetic acid and $0.02 \mathrm{~N} \mathrm{HCl}$ containing $10 \mathrm{mM}$ EDTA, $1 \mu \mathrm{g} / \mathrm{ml}$ pepstatin, and $0.01 \% \beta$-mercaptoethanol. The homogenates were centrifuged at $10,000 \mathrm{~g}$ for $30 \mathrm{~min}$ at $4^{\circ} \mathrm{C}$, and the supernatants were frozen in a dry ice-methanol bath, lyophilized, and stored at $-20^{\circ} \mathrm{C}$ until assayed. The anterior pituitaries were homogenized by polytron in $0.05 \mathrm{M} \mathrm{NaHCO}_{3}-\mathrm{Na}_{2} \mathrm{CO}_{3}$ buffer, $\mathrm{pH}$ 9.96. The homogenates were supplemented with an equal volume of $0.01 \mathrm{M}$ PBS containing $1 \%$ BSA, $0.1 \%$ Triton $\mathrm{X}-100$, and $25 \mathrm{mM}$ EDTA and stored at $-20^{\circ} \mathrm{C}$ until assayed for rat $\mathrm{GH}$.

\section{Reverse-phase HPLC}

A total of 10-12 hypothalami of hyper- or hypothyroid rats and their controls were incubated in a depolarizing $\left(50 \mathrm{mM} \mathrm{K}^{+}\right)$condition for two successive 30-min periods. The medium $(6.0-7.2 \mathrm{ml})$ was pooled, acidified by the addition of $0.3 \mathrm{M}$ TFA to a final concentration of 0.06 $\mathbf{M}$, and extracted on disposable Sep-Pak C18 cartridges (Waters Chromatographic Division, Millipore Corp., Bedford, MA) as described by Frohman and Downs (32). The cartridges were preactivated by successive $4-\mathrm{ml}$ washes of $0.01 \mathrm{M}$ TFA, $80 \%$ ( vol $/ \mathrm{vol}$ ) $\mathrm{CH}_{3} \mathrm{CN} / 20 \%$ (vol/ vol ) $0.01 \mathrm{M} \mathrm{TFA}$, and $0.01 \mathrm{M}$ TFA. After the samples were applied, the cartridges were washed with $4 \mathrm{ml}$ of $0.01 \mathrm{M}$ TFA, and GRF was eluted with $2 \mathrm{ml}$ of $80 \%$ ( vol $/ \mathrm{vol}$ ) $\mathrm{CH}_{3} \mathrm{CN} / 20 \%$ ( vol $/ \mathrm{vol}$ ) $0.01 \mathrm{M}$ TFA. The eluant was freeze-dried and reconstituted in a twentieth the original medium volume of $0.01 \mathrm{M}$ TFA for HPLC analysis. The HPLC system (Waters Chromatographic Division, Millipore Corp.) consisted of 600 E multisolvent delivery system, U6K universal liquid chromatography injector, and programmable multiwavelength detector. Reverse-phase HPLC column was Vydac $218 \mathrm{TP} 54(\mathrm{C} 18,0.46 \times 25 \mathrm{~cm}, 5-\mu \mathrm{m}$ particle size) (The Separation group, Hesperia, CA). Solvent A was $0.1 \%$ (vol/ vol) TFA and solvent B was $80 \%$ (vol/vol) $\mathrm{CH}_{3} \mathrm{CN} / 20 \%$ (vol/vol) 2-propanol $/ 0.1 \%$ ( vol/vol) TFA. The samples were eluted with a linear gradient of $25-45 \%(\mathrm{vol} / \mathrm{vol}$ ) solvent $B$ in $32 \mathrm{~min}$ and then $45-80 \%$ ( $\mathrm{vol} / \mathrm{vol}$ ) solvent $B$ in $28 \mathrm{~min}$. Flow rate was $1 \mathrm{ml} / \mathrm{min}$. 1-ml fractions were collected, lyophilized, and assayed for GRF. Blank injections were carried out before each sample injection, and fractions collected did not contain any detectable GRF-like immunoreactivity. The final recovery of synthetic GRF was $\sim 64 \%$.

\section{RIAs for rat GRF, GH, $T_{4}$, and IGF-I}

GRF in the medium and tissue samples was determined by RIA as described elsewhere (24). The minimum detectable dose $\left(\mathrm{B}_{0}-2 \mathrm{SD}\right)$ was $2 \mathrm{pg} /$ tube, with half-maximal displacement of $22-25 \mathrm{pg} /$ tube. The nonspecific binding was $<2 \%$. The samples were measured directly without extraction or concentration. In assays of the medium samples, HKRB buffer was added to all standard curves in a volume of 100-200 $\mu l$ equivalent to that of the unknown. The total incubation volume was $500 \mu \mathrm{l}$. Pituitary GH contents were measured in duplicate by a specific rat GH RIA $(5,12,24)$ at two dilutions using materials provided by the Rat Pituitary Hormone Distribution Program, National Institute of Diabetes and Digestive and Kidney Diseases (NIDDK) National Institutes of Health. Results were expressed in terms of NIDDK rat GH RP-2 reference standard. Serum $\mathrm{T}_{4}$ levels were determined by a double antibody method with a RIA kit purchased from Eiken ICL (Tokyo, Japan ). The sensitivity of the $T_{4}$ assay was $1 \mu \mathrm{g} / \mathrm{dl}$. Serum IGF-I levels were measured by RIA as described (33), using biosynthetic human IGF-I as standards and an antiserum not cross-reactive with IGF-II. Serum samples were extracted by the aceton-formic acid method of Bowsher et al. (34). The least detectable level of IGF-I assay was 10 $\mathrm{pg} /$ tube.

\section{Data analysis}

Results were expressed as means \pm SE. Analysis of variance was used for statistical analysis. Relationship between serum $\mathrm{T}_{4}$ and GRF secretion in hyperthyroid rats was analysed using linear regression analysis. Subsequent to analysis of variance, the significance of differences between experimental groups was determined by the Student-Newman-Keuls test. A $P$ value of $<0.05$ was considered statistically significant. 


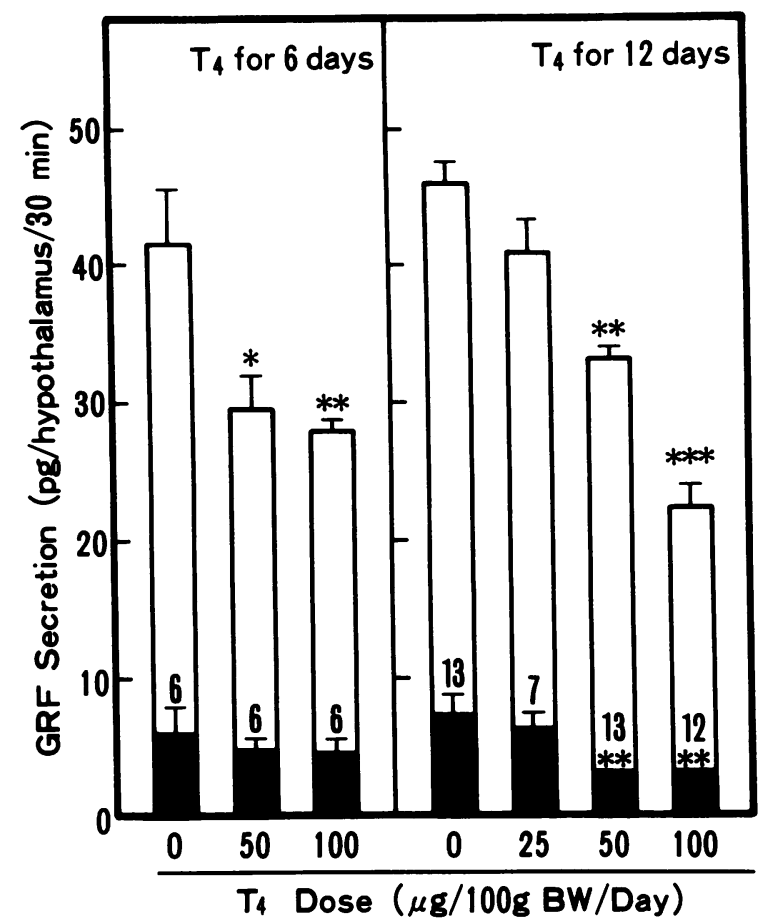

Figure 1. GRF secretion from hypothalamic fragments of rats rendered hyperthyroid by administration of $\mathrm{T}_{4}$ for 6 (left panel) or $12 \mathrm{~d}$ (right panel). Closed and open columns indicate basal and $50 \mathrm{mM}$ $\mathrm{K}^{+}$-stimulated GRF release, respectively. Two hypothalami were incubated in one vial, and the secretion of GRF was expressed as picograms (means $+\mathrm{SE}$ ) per hypothalamus / $30 \mathrm{~min}$. The numbers of observations were shown on the top of closed columns. ${ }^{*} P<0.05,{ }^{* *} P$ $<0.01,{ }^{* * *} P<0.001$ vs. control indicated by a zero dose of $\mathrm{T}_{4}$

\section{Results}

Effects of hyperthyroidism on hypothalamic GRF, pituitary $G H$, and serum $T_{4}$

Fig. 1 shows the results of secretion experiments in hyperthyroid rats. As shown in the left panel, administration of $T_{4}$ for 6 $\mathrm{d}$ had no effect on basal GRF secretion (closed columns) but significantly inhibited $\mathrm{K}^{+}$-evoked GRF secretion (open columns). The extent of GRF suppression was not different between two doses of $\mathrm{T}_{4}:-28.9 \%(P<0.05)$ by $50 \mu \mathrm{g}$ and
$-31.3 \%(P<0.01)$ by $100 \mu \mathrm{g} \mathrm{T}_{4} / 100 \mathrm{~g}$ per $\mathrm{d}$. Administration of $\mathrm{T}_{4}$ for $12 \mathrm{~d}$ inhibited GRF secretion (right panel) and increased serum $\mathrm{T}_{4}$ levels (Table I). Both effects were dose related, and the inhibitory effect on GRF secretion was greater than that observed after $6 \mathrm{~d}$ of $\mathrm{T}_{4}$ administration. Basal GRF secretion was inhibited below the assay detection limit $(P$ $<0.01$ ) by both of the 50 and $100 \mu \mathrm{g} / 100 \mathrm{~g}$ doses. $\mathrm{K}^{+}$-evoked GRF secretion was suppressed by $10.3 \%$ (NS), $27.3 \%$ ( $P$ $<0.01)$, and $50.1 \%(P<0.001)$ by the 25,50 , and $100 \mu \mathrm{g} / 100$ $\mathrm{g}$ doses of $\mathrm{T}_{4}$, respectively. Linear regression analysis showed a significant negative relationship $(r=-0.77, P<0.0001)$ between serum $\mathrm{T}_{4}$ levels and $\mathrm{K}^{+}$-evoked GRF secretion (data not illustrated).

The $\mathrm{T}_{4}$-induced suppression of GRF secretion after $12 \mathrm{~d}$ was associated with a parallel dose-related decline in pituitary $\mathrm{GH}$ ( Table I). The decline in GH was significant at an intermediate dose of $\mathrm{T}_{4}(-18.5 \%, P<0.01)$, and the minimum GH level at the highest dose was $60.7 \%(P<0.001)$ of the control value. $T_{4}$ at the highest dose also reduced pituitary $\mathrm{GH}$ after 6 $\mathrm{d}$, but to a lesser extent $(-10.6 \%, P<0.05)$ than after $12 \mathrm{~d}$ (Table I). Hypothalamic GRF contents were diminished only after administration of the highest dose for $12 \mathrm{~d}(-16.4 \%, P$ $<0.05$ ) (Table I).

At the beginning of $\mathrm{T}_{4}$ treatment for $12 \mathrm{~d}$, mean $( \pm \mathrm{SE}) \mathrm{BW}$ of all animals was $378 \pm 5 \mathrm{~g}(n=90)$, and those after treatment were $412 \pm 4(n=26), 399 \pm 6(n=14), 366 \pm 7(n=26)$, or $329 \pm 6 \mathrm{~g}(n=24)(P<0.001$ vs. initial weight $)$ in rats given 0 (vehicle), 25, 50, or $100 \mu \mathrm{g} \mathrm{T}_{4} / 100 \mathrm{~g}$ per d, respectively. After administration of $\mathrm{T}_{4}$ for $6 \mathrm{~d}$, the initial BW was significantly decreased also at the highest dose only $(-7.6 \%, P<0.01)$.

\section{Effects of hypothyroidism and $T_{4}$ or $h G H$ replacement on hypothalamic GRF secretion in vitro}

As shown in Fig. 2, $\mathrm{T}_{\mathrm{x}}$ significantly enhanced both basal (closed columns) and $\mathrm{K}^{+}$-stimulated GRF secretion (open columns) at $5 \mathrm{wk}$ after operation. Replacement of $\mathrm{T}_{4}$ for $7 \mathrm{~d}$ at 2 $\mu \mathrm{g} / 100 \mathrm{~g}$ per $\mathrm{d}$ partially reversed the $\mathrm{T}_{\mathrm{x}}$-induced rise in $\mathrm{K}^{+}$-stimulated GRF secretion $(-53 \%, P<0.01)$, whereas the enhanced basal GRF secretion was reversed $(P<0.01)$ to a level statistically indistinguishable from that of the sham- $T_{x}$ rats ( left panel). However, hGH treatment for $7 \mathrm{~d}$ at $200 \mu \mathrm{g} / \mathrm{rat}$ per $d$ had no inhibitory effect on the enhanced GRF secretion either basally or under $\mathrm{K}^{+}$stimulation in $\mathrm{T}_{\mathrm{x}}$ rats (right panel). $\mathrm{T}_{\mathrm{x}}$ rats weighed $\sim 30 \%$ less than sham $\mathrm{T}_{\mathrm{x}}$ controls at $4 \mathrm{wk}$ after

Table I. Serum $T_{4}$, Pituitary GH, and Hypothalamic GRF Levels in Hyperthyroid Rats

\begin{tabular}{|c|c|c|c|c|c|c|}
\hline Treatment & Dose & Length & $\begin{array}{c}\text { Number } \\
\text { of rats }\end{array}$ & Serum $T_{4}$ & Pituitary GH & Hypothalamic GRF \\
\hline & $\mu g$ & days & & $\mu g / d l$ & $\mu g /$ gland & pg/tissue \\
\hline Vehicle & & 6 & 12 & ND & $459 \pm 15$ & $858 \pm 53$ \\
\hline$T_{4}$ & 50 & 6 & 12 & ND & $459 \pm 23$ & $817 \pm 47$ \\
\hline $\mathrm{T}_{4}$ & 100 & 6 & 12 & ND & $410 \pm 22 *$ & $902 \pm 23$ \\
\hline Vehicle & & 12 & 26 & $5.4 \pm 0.1$ & $453 \pm 22$ & $719 \pm 23$ \\
\hline $\mathrm{T}_{4}$ & 25 & 12 & 14 & $12.7 \pm 0.5^{\S}$ & $408 \pm 20$ & $775 \pm 41$ \\
\hline$T_{4}$ & 50 & 12 & 26 & $15.4 \pm 0.8^{\S}$ & $369 \pm 16^{\ddagger}$ & $781 \pm 32$ \\
\hline $\mathrm{T}_{4}$ & 100 & 12 & 24 & $18.2 \pm 0.6^{\S}$ & $275 \pm 12^{\S}$ & $601 \pm 27^{*}$ \\
\hline
\end{tabular}

Results are means \pm SE. ND, not determined. Doses of $\mathrm{T}_{4}$ are expressed as $\mu \mathrm{g} / 100 \mathrm{~g}$ body weight/day. Tissue GRF levels were measured by pooling two hypothalami and are expressed as picograms per one hypothalamus. ${ }^{*} P<0.05,{ }^{\ddagger} P<0.01,{ }^{\S} P<0.001$ vs. vehicle. 


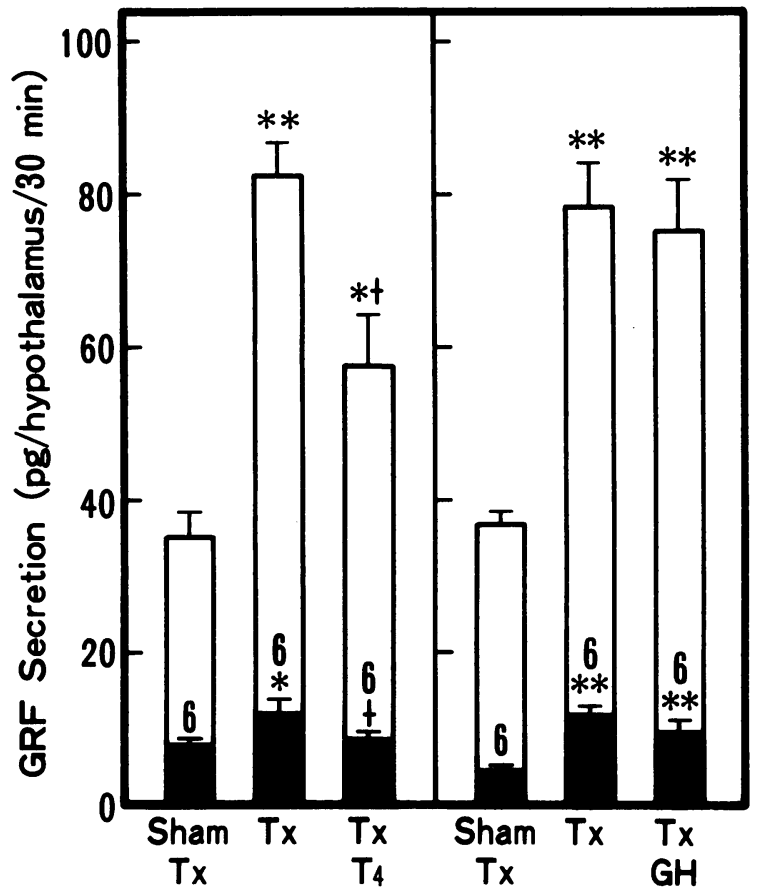

Figure 2. Effects of thyroidectomy $\left(T_{x}\right)$ and replacement of $\mathrm{T}_{4}$ (left panel) or hGH (right panel) for $7 \mathrm{~d}$ on GRF secretion from incubated hypothalamic fragments. $T_{x}$ rats were treated once daily with $T_{4}(2$ $\mu \mathrm{g} / 100 \mathrm{~g})$ or twice daily with $\mathrm{hGH}(100 \mu \mathrm{g} / \mathrm{rat})$ beginning at $4 \mathrm{wk}$ after $\mathrm{T}_{\mathrm{x}}$. Closed and open columns indicate basal and $50 \mathrm{mM} \mathrm{K}^{+}$. evoked secretion, respectively. The results were expressed as picograms (means +SE) of GRF secreted from one hypothalamus per 30 $\mathrm{min}$. The numbers of observations were shown on the top of closed columns. ${ }^{*} P<0.05,{ }^{* *} P<0.001$ vs. sham $\mathrm{T}_{\mathrm{x}} . \dagger P<0.01$ vs. $\mathrm{T}_{\mathrm{x}}$.

operation. hGH increased their BWs at a rate comparable to that of $T_{4}$. During $7 \mathrm{~d}$ of treatments, the mean $( \pm \mathrm{SE})$ weight gain of sham $T_{x}, T_{x}$, or $T_{x}+T_{4}$ groups was $29.2 \pm 2.3,4.7 \pm 2.5$, or $22.5 \pm 1.4 \mathrm{~g} / \mathrm{rat}$, and that of sham $\mathrm{T}_{\mathrm{x}}, \mathrm{T}_{\mathrm{x}}$, or $\mathrm{T}_{\mathrm{x}}+\mathrm{hGH}$ groups was $33.5 \pm 3.1,4.2 \pm 1.5$, or $25.2 \pm 2.7 \mathrm{~g} /$ rat $(n=12$ each), respectively.

$T_{x}$ rats were then replaced with $T_{4}$ or hGH for $14 \mathrm{~d}$ at the same daily dose (Fig. 3). $T_{4}$ reversed the $T_{x}$-induced rise in $\mathrm{K}^{+}$-stimulated GRF secretion by $76 \%(P<0.01)$. Although

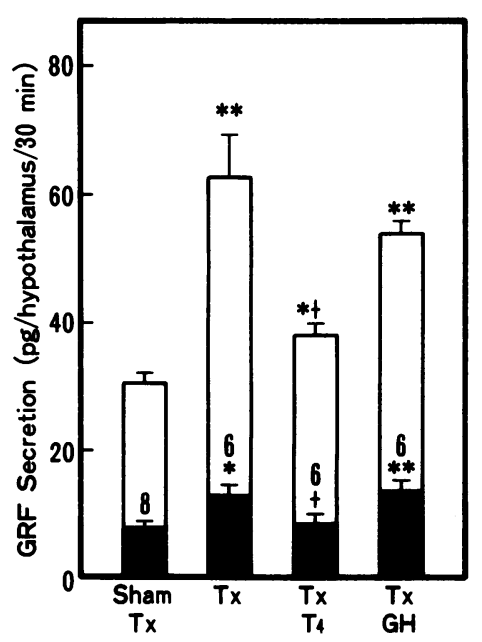

Figure 3. Effects of replacement of $\mathrm{T}_{4}$ or hGH for 14 $d$ on GRF secretion in $T_{x}$ rats. $T_{4}$ was given once daily at $2 \mu \mathrm{g} / 100 \mathrm{~g}$ and hGH twice daily at $100 \mu \mathrm{g} /$ rat beginning at $4 \mathrm{wk}$ after $T_{x}$. Sham $T_{x}$ and control $T_{x}$ rats were treated with vehicles for both $\mathrm{T}_{4}$ and hGH. Closed and open columns indicate basal and $50 \mathrm{mM}$ $\mathrm{K}^{+}$-evoked GRF secretion, respectively. The secretion of GRF was expressed as picograms (means $+\mathrm{SE}$ ) per hypothalamus $/ 30 \mathrm{~min}$. ${ }^{*} P<0.01,{ }^{* *} P<0.001$ vs. sham $\mathrm{T}_{\mathrm{x}} \cdot{ }^{\dagger} P<0.01$ vs. $\mathrm{T}_{\mathrm{x}}$. not complete, this reversibility was greater than that observed after $7 \mathrm{~d}$ (Fig. 2). $\mathrm{T}_{4}$ suppressed the enhanced basal GRF secretion completely $(P<0.01)$, as it did after $7 \mathrm{~d}$. At a half daily dose of $1 \mu \mathrm{g} / 100 \mathrm{~g}, \mathrm{~T}_{4}$ replaced for $14 \mathrm{~d}$ was also effective, though to a lesser extent, in inhibiting the enhanced $\mathrm{K}^{+}$evoked GRF secretion (data not shown). In contrast, hGH did not significantly reduce either basal or $\mathrm{K}^{+}$-stimulated GRF secretion in $\mathrm{T}_{\mathrm{x}}$ rats. However, $\mathrm{hGH}$ restored their diminished weight gains to normal. During $14 \mathrm{~d}$ of treatments, the mean $\left( \pm S E\right.$ ) weight gain of sham $T_{x}, T_{x}, T_{x}+T_{4}$, or $T_{x}+h G H$ groups was $48.8 \pm 5.0,5.3 \pm 1.2,49.4 \pm 2.8$, or $51.1 \pm 2.8 \mathrm{~g} / \mathrm{rat}(n$ $=12-16)$, respectively.

The third experiment with hGH was carried out to study the effect of combined $h \mathrm{hH}$ and $\mathrm{T}_{4}$ replacement in $\mathrm{T}_{\mathrm{x}}$ rats (Fig. 4). The doses of $\mathrm{T}_{4}$ and $\mathrm{hGH}$ were the same with those shown in Figs. 2 and 3, and the length of treatments was $7 \mathrm{~d}$. $\mathrm{T}_{4}$ alone partially reversed the enhanced $\mathrm{K}^{+}$-evoked GRF secretion $(P$ $<0.01$ ) while normalizing the increased basal secretion. hGH in combination with $\mathrm{T}_{4}$ similarly reversed the enhanced $\mathrm{K}^{+}$evoked GRF secretion significantly $(P<0.01)$, but the level reversed by the combined $\mathrm{hGH}$ and $\mathrm{T}_{4}$ therapy was statistically not different from that attained by $\mathrm{T}_{4}$ alone. $\mathrm{hGH}$ and $\mathrm{T}_{4}$ replaced together increased the mean $( \pm S E)$ weight gain of $T_{x}$ rats from $3.0 \pm 2.1$ to $33.4 \pm 0.9 \mathrm{~g} /$ rat during $7 \mathrm{~d}$ of treatment, which was significantly greater than that of sham $T_{x}$ rats $(26.7 \pm 3.1, P<0.05)$ or $\mathrm{T}_{4}$-treated $\mathrm{T}_{\mathrm{x}}$ rats $(21.6 \pm 3.5, P<0.01)$ ( $n=12$ each).

Serum $T_{4}$, serum IGF-I, pituitary $G H$, and hypothalamic GRF levels in hypothyroid rats and effects of $T_{4}$ or $h G H$ replacement

As shown in Table II, $\mathrm{T}_{\mathrm{x}}$ reduced serum $\mathrm{T}_{4}$ to undetectable levels $(<1 \mu \mathrm{g} / \mathrm{dl})(P<0.001)$, serum IGF-I by $36.5-38.6 \%(P$ $<0.001)$, and hypothalamic GRF contents by $25.7-34.3 \%$ ( $P$ $<0.05-0.01$ ). Replacement of $\mathrm{T}_{4}$ for 7 and $14 \mathrm{~d}$ restored the decreased serum $\mathrm{T}_{4}$ and hypothalamic GRF to levels higher than those in sham $T_{x}$ rats, whereas hGH treatment was without effect on either parameter. The decreased serum IGF-I levels were significantly restored by $\mathrm{T}_{4}\left(P<0.01\right.$ vs. $\left.\mathrm{T}_{\mathrm{x}}\right)$ to 74.3 and $85.6 \%$ of the value of sham $T_{x}$ animals after 7 and $14 \mathrm{~d}$, respectively. hGH treatment for $7 d$ had no effect on the $T_{x}$-in-

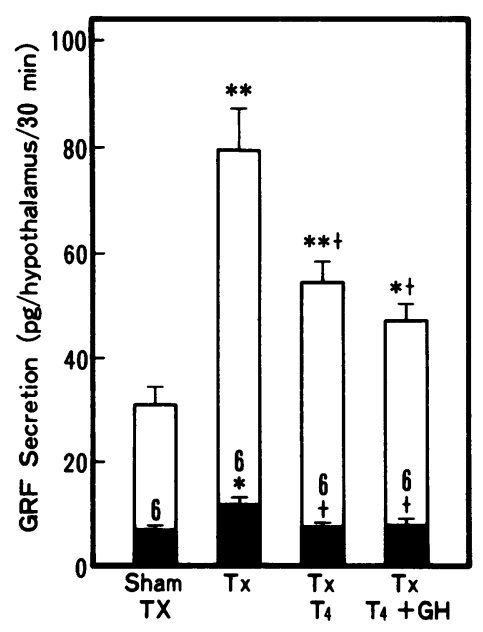

Figure 4. Effects of replacement of hGH in combination with $\mathrm{T}_{4}$ for $7 \mathrm{~d}$ on GRF secretion in $T_{x}$ rats. The doses of $T_{4}$ and $h G H$ were the same with those shown in Figs. 2 and 3: $T_{4}$, $2 \mu \mathrm{g} / 100 \mathrm{~g}$ per $\mathrm{d}$ in a single dose and hGH, $200 \mu \mathrm{g} / \mathrm{rat}$ per $\mathrm{d}$ in two divided doses. Sham $T_{x}$ and control $T_{x}$ animals received vehicles for both $\mathrm{T}_{4}$ and $\mathrm{hGH}$. Treatments started at $4 \mathrm{wk}$ after $T_{x}$. Closed and open columns indicate basal and $50 \mathrm{mM} \mathrm{K}^{+}$-evoked GRF secretion, respectively. The secretion of GRF was expressed as picograms (means $+\mathrm{SE}$ ) per hypothalamus $/ 30 \mathrm{~min}$. ${ }^{*} P<0.01,{ }^{* *} P<0.001$ vs. sham $\mathrm{T}_{\mathrm{x}} \cdot{ }^{\dagger} P<0.01$ vs. $\mathrm{T}_{\mathrm{x}}$. 
Table II. Serum $T_{4}$, Serum IGF-I, and Hypothalamic GRF Levels in Thyroidectomized $\left(T_{x}\right)$ Rats Treated with $T_{4}$ or $h G H$

\begin{tabular}{|c|c|c|c|c|c|}
\hline Group & Length & $\begin{array}{l}\text { Number } \\
\text { of rats }\end{array}$ & Serum $T_{4}$ & Serum IGF-I & Hypothalamic GRF \\
\hline & days & & $\mu g / d l$ & $n g / m l$ & pg/tissue \\
\hline Sham $T_{x}$ & 7 & 12 & $5.9 \pm 0.2$ & $441 \pm 6$ & $803 \pm 35$ \\
\hline $\mathrm{T}_{\mathrm{x}}$ & 7 & 12 & $<1.0^{\S}$ & $280 \pm 8^{\S}$ & $596 \pm 58^{*}$ \\
\hline$T_{x}+T_{4}$ & 7 & 12 & $8.6 \pm 0.7^{\ddagger 1}$ & $328 \pm 7^{\ddagger 1}$ & $1068 \pm 48^{\prime}$ \\
\hline Sham $T_{x}$ & 7 & 12 & $5.6 \pm 0.1$ & $391 \pm 14$ & $726 \pm 65$ \\
\hline $\mathrm{T}_{\mathrm{x}}$ & 7 & 12 & $<1.0^{\S}$ & $243 \pm 7^{\S}$ & $501 \pm 24^{*}$ \\
\hline $\mathrm{T}_{\mathrm{x}}+\mathrm{hGH}$ & 7 & 12 & $<1.0^{\S}$ & $261 \pm 8^{\S}$ & $543 \pm 52^{*}$ \\
\hline Sham $T_{x}$ & 14 & 16 & $6.1 \pm 0.1$ & $396 \pm 14$ & $1023 \pm 68$ \\
\hline $\mathrm{T}_{\mathrm{x}}$ & 14 & 12 & $<1.0^{\S}$ & $243 \pm 9^{\S}$ & $672 \pm 74^{\ddagger}$ \\
\hline$T_{x}+T_{4}$ & 14 & 12 & $8.9 \pm 1.2^{\ddagger 1}$ & $339 \pm 15^{* 1}$ & $1359 \pm 37^{* 1}$ \\
\hline $\mathrm{T}_{\mathrm{x}}+\mathrm{hGH}$ & 14 & 12 & $<1.0^{\S}$ & $329 \pm 8^{\ddagger 1}$ & $734 \pm 85^{*}$ \\
\hline
\end{tabular}

Results are the means \pm SE. Tissue GRF levels were measured by pooling two hypothalami and are expressed as picograms per one hypothalamus. ${ }^{*} P<0.05,{ }^{\ddagger} P<0.01,{ }^{\S} P<0.001$ vs. sham $\mathrm{T}_{\mathrm{x}}$. ${ }^{\prime} P<0.01,{ }^{\prime} P<0.001$ vs. $\mathrm{T}_{\mathrm{x}}$.

duced decrease in serum IGF-I levels. However, hGH given for 14 d increased it significantly $\left(P<0.001\right.$ vs. $\left.T_{x}\right)$ to $83.0 \%$ of the euthyroid value, which was comparable to that in hypothyroid rats treated with $\mathrm{T}_{4}$ for the same duration.

$\mathrm{T}_{\mathrm{x}}$ depleted pituitary $\mathrm{GH}$ contents to $<1 \%$ of that of euthyroid rats $(P<0.001)$ at $5-6 \mathrm{wk}$ after operation, and the reduced pituitary GH was significantly $(P<0.001)$ reversed by $\mathrm{T}_{4}$ (Table III). This reversibility was greater by replacement of $\mathrm{T}_{4}$ at a higher dose ( $2 \mathrm{vs} .1 \mu \mathrm{g} / 100 \mathrm{~g}$ per $\mathrm{d})$ when the length of treatment was same, or by replacement for a longer duration ( $14 \mathrm{vs.}$ $7 \mathrm{~d}$ ) when the dose of $\mathrm{T}_{4}$ was same. With the replacement of $\mathrm{T}_{4}$ at $2 \mu \mathrm{g} / 100 \mathrm{~g}$ per d for $14 \mathrm{~d}$, the decreased pituitary GH was restored to the maximum level of $82 \%$ of that of sham $T_{x}$ rats, although this level remained significantly lower $(P<0.001)$ than the euthyroid value.

\section{Characterization of hypothalamic GRF in the medium}

Fig. 5 shows reverse-phase HPLC elution profiles of immunoreactive GRF in hyper- and hypothyroid animals and their con-

Table III. Effects of Thyroidectomy $\left(T_{x}\right)$ and Replacement of $T_{4}$ or hGH on Pituitary GH Contents

\begin{tabular}{|c|c|c|c|c|c|}
\hline Group & Treatment & Dose & Length & $\begin{array}{l}\text { Number } \\
\text { of rats }\end{array}$ & Pituitary GH \\
\hline & & $\mu g$ & days & & $\mu g /$ gland \\
\hline Sham $T_{x}$ & Vehicle & & 7,14 & 80 & $393 \pm 5(100)$ \\
\hline $\mathrm{T}_{\mathrm{x}}$ & Vehicle & & 7,14 & 64 & $2.1 \pm 0.1(0.5)$ \\
\hline$T_{x}$ & $\mathrm{~T}_{4}$ & 1 & 7 & 14 & $142 \pm 16^{*}(36)$ \\
\hline$T_{x}$ & $\mathrm{~T}_{4}$ & 2 & 7 & 12 & $183 \pm 11^{*}(46)$ \\
\hline$T_{x}$ & $\mathrm{~T}_{4}$ & 1 & 14 & 14 & $243 \pm 12 *(61)$ \\
\hline$T_{x}$ & $\mathrm{~T}_{4}$ & 2 & 14 & 12 & $324 \pm 10^{*}(82)$ \\
\hline$T_{x}$ & hGH & 200 & 7 & 12 & $1.7 \pm 0.4(0.4)$ \\
\hline$T_{x}$ & hGH & 200 & 14 & 12 & $2.8 \pm 0.6(0.7)$ \\
\hline
\end{tabular}

Results are means \pm SE; values in parentheses are percentages. Pituitary GH contents in sham $T_{x}$ or $T_{x}$ rats treated with vehicle for 7 or 14 days were combined. ${ }^{*} P<0.001$ vs. sham $T_{x}+$ vehicle or $T_{x}+$ vehicle. trols, which was secreted in vitro in response to $50 \mathrm{mM} \mathrm{K}^{+}$. Rats were given vehicle or $\mathrm{T}_{4}$ at $100 \mu \mathrm{g} / 100 \mathrm{~g}$ per d for $6 \mathrm{~d}$ (left panels), or received sham $T_{x}$ or $T_{x} 5$ wk ago (right panels). In all of these groups, a major proportion of immunoreactive GRF was eluted at a position identical to that of synthetic GRF. This indicates that by HPLC criteria, rat GRF secreted into the medium was indistinguishable from synthetic peptide. A small portion of GRF-like immunoreactivity also was detected at later fraction(s) than that of authentic rat GRF, but the nature of these small immunoreactive peaks is unknown. An elution profile of GRF of $T_{x}$ rats treated with $T_{4}(2 \mu \mathrm{g} / 100$ g per d) or hGH $(200 \mu \mathrm{g} /$ rat per d $)$ for $7 \mathrm{~d}$ was similar to that of sham $T_{x}$ or $T_{x}$ rats (data not illustrated).

\section{Discussion}

Both thyroid hormone and GRF are the physiological factors that act directly at the pituitary somatotroph and facilitate its functional activity. Their actions were similar in many aspects, which include stimulation of $\mathrm{GH}$ gene transcription, mRNA levels, biosynthesis, and secretion (4-8, 14-19). The results of the present studies demonstrate that thyroid hormone also affects the secretion of hypothalamic GRF, the GH-regulatory peptide. The effects of thyroid hormone excess and deficiency on GRF secretion were opposite, and there was an inverse relationship between serum $\mathrm{T}_{4}$ levels and GRF secretion. This finding clearly indicates an inhibitory role of thyroid hormone in GRF secretion. Characterization of GRF in the medium by reverse-phase HPLC revealed that the molecular form of GRF peptide was not altered by an abnormal thyroid status.

The inhibition of GRF secretion by thyroid hormone occurs at physiological concentrations in serum. This is indicated by the findings that thyroid gland ablation enhanced GRF secretion and that this effect was highly reversible by replacement of $T_{4}$ at physiological doses. Also, at thyrotoxic doses, $T_{4}$ suppressed GRF secretion in normal rats. These effects of thyroid hormone status on GRF secretion are probably not simply the result of weight changes or altered food intake. First, hyperand hypothyroidism similarly diminished BWs, while exhibiting an opposite effect on GRF secretion. Second, the inhibition of GRF secretion by thyrotoxicosis was already significant at 


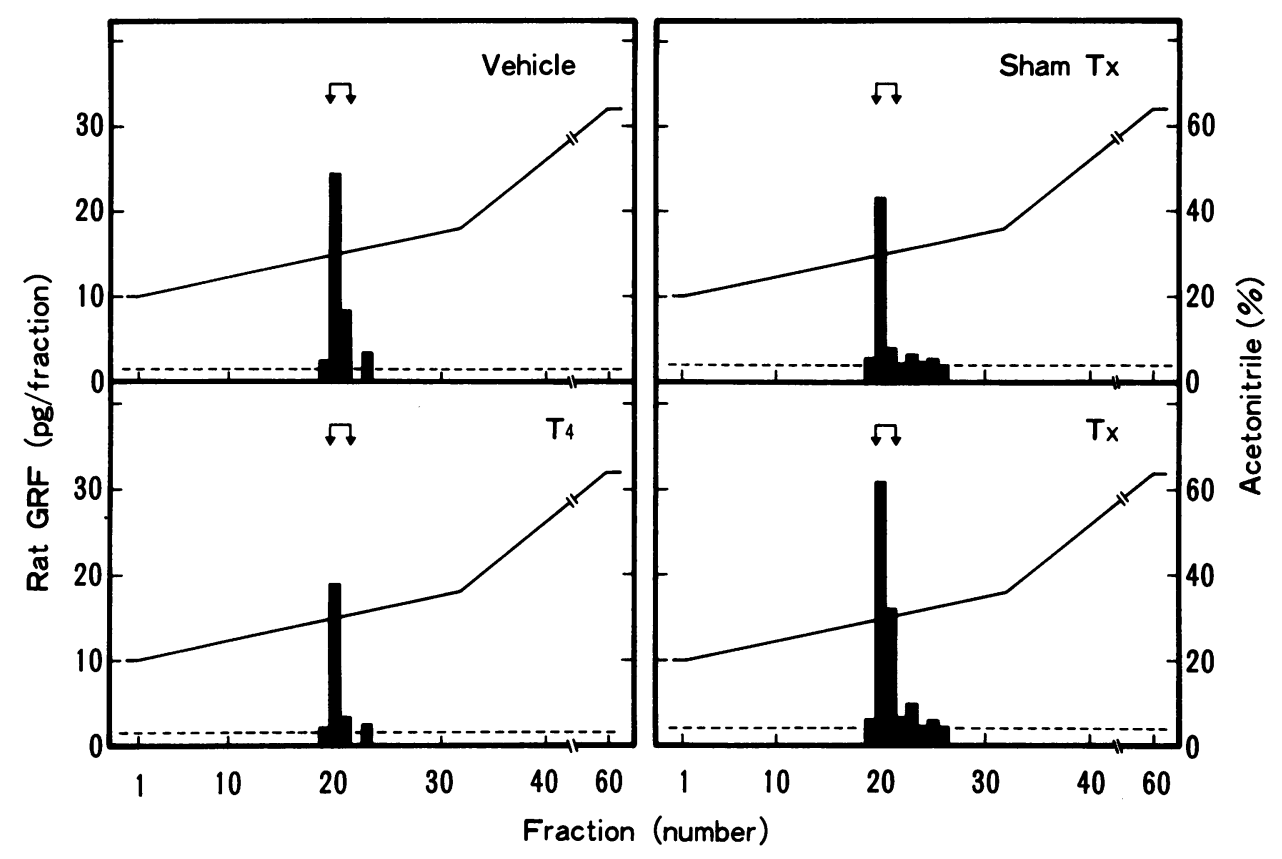

Figure 5. Reverse-phase HPLC of immunoreactive hypothalamic GRF secreted in vitro from hypothalami of hyper- and hypothyroid rats and their controls. Left panels, elution profiles of GRF of rats administered with vehicle (upper panel) or $\mathrm{T}_{4}$ $(100 \mu \mathrm{g} / 100 \mathrm{~g}$ per d) (lower panel) for $6 \mathrm{~d}$. Right panels, elution profiles of GRF of sham $T_{x}$ ( upper panel) or $\mathrm{T}_{\mathrm{x}}$ (lower panel) rats $5 \mathrm{wk}$ after operation. Arrows indicate elution positions of synthetic rat GRF. Results were expressed as picograms/hypothalamus per 30 min per fraction. Broken lines indicate the detection limit. the intermediate dose of $\mathrm{T}_{4}$, which did not reduce initial BWs of animals. Third, hyperthyroidism promotes and hypothyroidism depresses food intake (35), whereas food deprivation decreases GRF mRNA levels (36) and GRF secretion in the rat (unpublished observation). Therefore, if thyroid hormone acted by altering food intake, it would have been the hypothyroid but not hyperthyroid rats who showed the diminished GRF secretion.

Consistent with a modulatory role in $\mathrm{GH}$ secretion, the effect that thyroid hormone exerted on GRF secretion was of a delayed type at both physiological and thyrotoxic doses. Although the decreased GRF contents in hypothyroid rats were fully recovered after $7 \mathrm{~d}$ of $\mathrm{T}_{4}$ replacement, the enhanced GRF secretion was not completely reversed after either 7 or $14 \mathrm{~d}$ of replacement. $T_{4}$ was without effect on GRF secretion when replaced for $4 d$ in $T_{x}$ rats (26). The suppression of GRF secretion in hyperthyroid rats was greater after administration of the highest dose of $\mathrm{T}_{4}$ for 12 than $6 \mathrm{~d}$, and the dose-response relationship became apparent after $12 \mathrm{~d}$. These results suggest that the effectiveness of thyroid hormone on GRF secretion is determined by the duration of its treatment as well as the dose administered.

It is well established that hypothyroidism causes a severe depletion of pituitary $\mathrm{GH}(14-16)$. As soon as $6 \mathrm{~h}$ after replacement, $T_{4}$ can start to increase the diminished GH (16), whereas little is known on a precise time course of its recovery to euthyroid level. The present studies give some information on this issue by replacing $T_{4}$ at physiological doses of 1 or 2 $\mu \mathrm{g} / 100 \mathrm{~g}$, each for 7 and $14 \mathrm{~d}$. However, replacement of $\mathrm{T}_{4}$ for $14 \mathrm{~d}$ was not sufficient to recover the diminished $\mathrm{GH}$ content completely. This is consistent with a morphological study of DeFesi et al. that 17-24 d of triiodothyronine $\left(T_{3}\right)$ replacement was required to normalize decreased somatotroph number in $T_{x}$ rats (37). In contrast, diminished $G H$ secretion in $T_{x}$ rats was normalized within $4 \mathrm{~d}$ after initiation of $T_{4}$ replacement (22). These findings, together with the present results on GRF, indicate that it takes $>14 \mathrm{~d}$ for replacement of $\mathrm{T}_{4}$ to normalize the whole of the altered hypothalamic GRF-pituitary $\mathrm{GH}$ axis in hypothyroid rats.

In addition to depleting pituitary $\mathrm{GH}$ contents, hypothyroidism also abolishes spontaneous GH secretion (20-22), suppresses GH response to GRF (38-40), and causes growth retardation (23). Qualitatively similar effects can be reproduced by GRF antibodies (4-6, 41) or its antagonists $(42,43)$. These findings initially led us to the hypothesis that hypothyroidism might cause somatotroph failure, at least in part, through inhibiting hypothalamic GRF secretion. By observing a decrease in GRF content after $T_{x}$ and its rapid recovery by replacement of $T_{4}$, Katakami et al. (22) also have suggested that a critical role of thyroid hormone in GH secretion is related to its effect on hypothalamic GRF. Later, we and others demonstrated that GRF secretion in vitro was rather enhanced in hypothyroid, GH-deficient rats $(26,29)$. We conclude, therefore, that the pituitary somatotroph failure in hypothyroidism is not caused by GRF deficiency and so most probably is a direct consequence of thyroid hormone deficiency. The same conclusion was obtained also in an in vivo study with neonatal hypothyroid rats (44).

The effect of hyperthyroidism on the hypothalamic-pituitary GH axis has been less clear. There is some evidence to suggest that thyrotoxicosis has an inhibitory influence on $\mathrm{GH}$. Hyperthyroidism causes a moderate decline in both pituitary GH and BWs in the neonatal rat $(45,46)$. Physiological GH secretion was diminished in human subjects with thyrotoxicosis and was normalized after they became euthyroid (47). The present studies have demonstrated that hyperthyroidism inhibits GRF secretion, concomitantly decreasing both BWs and pituitary GH in the adult rat. This finding, together with the report of Clark and Robinson (48) that GRF accelerates growth and increases GH content in rats, indicates that the decreased in vitro release of GRF in hyperthyroid rats is not due to an increased turnover rate of GRF in vivo. The parallel decline in GRF secretion, GH content, and possibly GH secretion as well suggests that the hypothalamus is a primary target 
tissue of hyperthyroidism in GH secretion. This view is supported by the finding that pituitary GH responsiveness to GRF in vivo was not affected or only minimally decreased in hyperthyroid rats $(49,50)$. Thus, at pathological conditions, thyroid hormone appears to negatively influence pituitary somatotroph function by two pathways: one in hyperthyroidism via the hypothalamus and the other in hypothyroidism leading directly to the pituitary. This difference in the primary target tissue could explain biphasic effects of thyroid hormone on growth rate (28) and pituitary GH contents.

At a supraphysiological concentration of $1.55 \times 10^{-6} \mathrm{M}$, the addition of $\mathrm{T}_{3}$ stimulates hypothalamic SRIF secretion in vitro (51). This effect is inhibitory for pituitary GH secretion, as was the effect that thyroid hormone excess exerted on GRF in the present studies. Hyperthyroidism may depress pituitary GH secretion through a dual effect on GRF and SRIF in the hypothalamus. Modulation of SRIF by thyroid hormone deficiency is conflicting. Hypothalamic SRIF secretion in vitro is reported to be decreased (51), unaltered (21), or enhanced (29) in hypothyroid rats. This may be due in part to the difference in the induction time or length of hypothyroidism or in the method of operation, thyroidectomy vs. thyroparathyroidectomy. Anyway, these discrepant studies seem to agree on that hypothyroid rats can continue to secrete a considerable proportion of SRIF, if its capacity is even decreased. However, it remains unknown whether SRIF inhibition of GH secretion is of any significance in severe hypothyroidism, in which GH is virtually absent in the bloodstream.

With replacement of hGH, we could not reverse the enhanced GRF secretion associated with GH deficiency in hypothyroid rats. At the dose and duration used, $\mathrm{hGH}$ was as potent as $T_{4}$ in restoring decreased body weight gains of $T_{x}$ rats. hGH also restored the diminished serum levels of IGF-I, a mediator of anabolic effects of GH (52). The effect of hGH on IGF-I induction was comparable to that of $\mathrm{T}_{4}$ after $14 \mathrm{~d}$ of replacement, although not significant after $7 \mathrm{~d}$. This finding agrees well with the earlier reports on hypothyroid adult rats treated with bovine GH for $7 \mathrm{~d}(53)$ or hGH for $14 \mathrm{~d}$ (54). Furthermore, unlike the effect on growth $(23,30,55)$, a combined hGH and $T_{4}$ therapy was not more effective than $T_{4}$ alone in inhibiting GRF secretion in hypothyroid rats. These results suggest that the increased GRF secretion in hypothyroidism is not mediated through the feedback mechanism involving either GH or IGF-I deficiency.

There is biochemical evidence to support that thyroid hormone acts directly at the level of the hypothalamus. The conversion of $T_{4}$ to its active metabolite $T_{3}$ is an important step in mediating the action of thyroid hormone on its nuclear receptor and has been considered the main source of $\mathrm{T}_{3}$ in the brain $(56,57)$. Type II $5^{\prime}$-monodeionase is an enzyme that deiodinates $T_{4}$ to $T_{3}$ in the brain (56), and the activity of this enzyme is highest in the arcuate nucleus and median eminence in brains of hypothyroid rats (58). Because these hypothalamic regions possess both cell bodies and nerve terminals of the hypophysiotrophic GRF neurons $(59,60), T_{3}$ generated locally in the hypothalamus could directly influence the functional activity of GRF neurons. This view may be supported by the significant correlation between serum $T_{4}$ levels and GRF secretion that we observed in hyperthyroid rats. Alternatively, thyroid hormone may act indirectly through altering metabolic and/or other factors of the central or peripheral origin.
Other laboratories have recently reported that hypothalamic GRF $m$ RNA levels in rats were increased in hypothyroid$\operatorname{ism}(26,27,61)$ and decreased in hyperthyroidism (61). This negative relationship between GRF mRNA and thyroid function is similar to that which we found between GRF secretion and serum $\mathrm{T}_{4}$. In their studies on hypothyroid rats, however, GH showed an inhibitory effect on GRF mRNA levels, whereas we observed that GH was without effect on GRF secretion. The increased GRF mRNA levels were completely reversed by $5 \mathrm{~d}$ of rat $\mathrm{GH}$ replacement in adult hypothyroid rats, and rat $\mathrm{GH}$ was more potent than $\mathrm{T}_{4}(26)$. It was also reversed by $\mathrm{hGH}$ in prepubertal hypothyroid rats, although $14 \mathrm{~d}$ of replacement was required for complete reversel (27). Thus, thyroid hormone modulates GRF mRNA levels and peptide secretion in a similar inhibitory mode. However, the underlying mechanisms are probably different, involving the $\mathrm{GH}$ feedback for GRF mRNA but not for GRF peptide secretion. Alternatively, GRF secretion might be less sensitive than GRF mRNA to the GH feedback signal or could respond to GH administered in a physiological pulsatile pattern only.

\section{Acknowledgments}

We thank the National Institute of Diabetes and Digestive and Kidney Diseases for supplying materials for rat GH RIA and Sumitomo Pharmaceutical Co. Ltd. for the generous gift of recombinant hGH.

This work was supported in part by a grant from the Growth Science Foundation.

\section{References}

1. Guillemin, R., P. Brazeau, P. Bohhlen, F. Esch, N. Ling, and W. B. Wehrenberg. 1982. Growth hormone-releasing factor from a human pancreatic tumor that caused acromegaly. Science (Wash. DC). 218:585-587.

2. Rivier, J., J. Spiess, M. Thorner, and W. Vale. 1982. Characterization of a growth hormone-releasing factor from a human pancreatic islet tumor. Nature (Lond.). 300:276-278.

3. Spiess, J., J. Rivier, and W. Vale. 1983. Characterization of rat hypothalamic growth hormone-releasing factor. Nature (Lond.). 303:532-535.

4. Wehrenberg, W. B., P. Brazeau, R. Luben, P. Bohlen, and R. Guillemin. 1982. Inhibition of the pulsatile secretion of growth hormone by monoclonal antibodies to the hypothalamic growth hormone releasing factor(GRF). Endocrinology. 111:2147-2148.

5. Miki, N., M. Ono, and K. Shizume. 1984. Evidence that opiatergic and $\alpha$-adrenergic mechanisms stimulate rat growth hormone release via growth hormone-releasing factor (GRF). Endocrinology. 114:1950-1952.

6. Ono, M., N. Miki, and H. Demura. 1991. Effect of antiserum to rat growth hormone $(\mathrm{GH})$-releasing factor on physiological $\mathrm{GH}$ secretion in the female rat. Endocrinology. 129:1791-1796.

7. Barinaga, M., G. Yamonoto, C. Rivier, W. Vale, R. Evans, and M. G. Rosenfeld. 1983. Transcriptional regulation of growth hormone gene expression by growth hormone-releasing factor. Nature (Lond.). 306:84-85.

8. Gick, G. G., F. N. Zeytin, P. Brazeau, N. C. Ling, F. S. Esch, and C. Bancroft. 1984. Growth hormone-releasing factor regulates growth hormone mRNA in primary cultures of rat pituitary cells. Proc. Natl. Acad. Sci. USA. 81:1553-1555.

9. Brazeau, P., W. Vale, R. Burgus, N. Ling, M. Butcher, J. Rivier, and R. Guillemin. 1973. Hypothalamic polypeptide that inhibits the secretion of immunoreactive pituitary growth hormone. Science (Wash. DC). 179:77-79.

10. Reichlin, S. 1983. Somatostatin. N. Engl. J. Med. 309:1495-1501

11. Plotsky, P. M., and W. Vale. 1985. Patterns of growth hormone-releasing factor and somatostatin secretion into the hypophysial-portal circulation in the rat. Science (Wash. DC). 230:461-463.

12. Miki, N., M. Ono, and K. Shizume. 1988. Withdrawal of endogenous somatostatin induces secretion of growth hormone-releasing factor in rats. $J$. Endocrinol. 117:245-252.

13. Reichlin, S. 1974. Regulation of somatotrophic hormone secretion. In Handbook of Physiology, Section 7: Endocrinology, Vol. IV: The Pituitary Gland 
and Its Neuroendocrine Control, Part 2. R. O. Greep and E. B. Astwood, section editors. American Physiological Society, Washington, DC. 405-447.

14. Peake, G. T., C. A. Birge, and W. H. Daughaday. 1973. Alterations of radioimmunoassayable growth hormone and prolactin during hypothyroidism. Endocrinology. 92:487-493.

15. Wilkins, J. N., S. E. Mayer, and W. P. VanderLaan. 1974. The effects of hypothyroidism and 2,4-dinitrophenol on growth hormone synthesis. Endocrinology. 95:1259-1267.

16. Hervas, F., G. Morreale de Escobar, and F. Escobar del Rey. 1975. Rapid effects of single small doses of L-thyroxine and triiodo-L-thyronine on growth hormone, as studied in the rat by radioimmunoassay. Endocrinology. 97:91-101.

17. Martial, J. A., J. D. Baxter, H. M. Goodman, and P. H. Seeburg. 1977. Regulation of growth hormone messenger RNA by thyroid and glucocorticoid hormones. Proc. Natl. Acad. Sci. USA. 74:1816-1820.

18. Seo, H., G. Vassart, H. Brocas, and S. Refetoff. 1977. Triiodothyronine stimulates specifically growth hormone mRNA in rat pituitary tumor cells. Proc. Natl. Acad. Sci. USA. 74:2054-2058.

19. Evans, R. M., N. C. Birnberg, and M. G. Rosenfeld. 1982. Glucocorticoid and thyroid hormones transcriptionally regulate growth hormone gene expression. Proc. Natl. Acad. Sci. USA. 79:7659-7663.

20. Takeuchi, A., M. Suzuki, and S. Tsuchiya. 1978. Effect of thyroidectomy on the secretory profiles of growth hormone, thyrotropin and corticosterone in the rat. Endocrinol. Jpn. 25:381-390.

21. Martin, D., J. Epelbaum, M.-T. Bluet-Pajot, M. Prelot, C. Kordon, and D. Durand. 1985. Thyroidectomy abolishes pulsatile growth hormone secretion without affecting hypothalamic somatostatin. Neuroendocrinology. 41:476-481.

22. Katakami, H., T. R. Downs, and L. A. Frohman. 1986. Decreased hypothalamic growth hormone-releasing hormone content and pituitary responsiveness in hypothyroidism. J. Clin. Invest. 77:1704-1711.

23. Scow, R. O., M. E. Simpson, C. W. Asling, C. H. Li, and H. M. Evans. 1949. Response by the rat thyro-parathyroidectomized at birth to growth hormone and to thyroxin given separately or in combination. Anat. Rec. 104:445463.

24. Miki, N., M. Ono, H. Miyoshi, T. Tsushima, and K. Shizume. 1989. Hypothalamic growth hormone-releasing factor (GRF) participates in the negative feedback regulation of growth hormone secretion. Life Sci. 44:469-476.

25. Maiter, D. M., S. M. Gabriel, J. I. Koenig, W. E. Russell, and J. B. Martin. 1990. Sexual differentiation of growth hormone feedback effects on hypothalamic growth hormone-releasing hormone and somatostatin. Neuroendocrinology. 51:174-180.

26. Downs, T. R., P. Chomczynski, and L. A. Frohman. 1990. Effects of thyroid hormone deficiency and replacement on rat hypothalamic growth hormone (GH)-releasing hormone gene expression in vivo are mediated by GH. Mol. Endocrinol. 4:402-408.

27. De Gennaro Colonna, V., G. Bertola, C. B. Coco, M. Bifano, D. Cocchi, A. Maggi, and E. E. Muller. 1991. Hypothalamic-pituitary somatotropic function in prepubertal hypothyroid rats: effect of growth hormone replacement therapy. Proc. Soc. Exp. Biol. Med. 196:432-437.

28. Ingbar, S. H., and K. A. Woeber. 1981. The thyroid gland. In Textbook of Endocrinology. R. H. Williams, editor. W. B. Saunders Co., Philadelphia, PA. 171-173.

29. Miki, N., M. Ono, T. Tsushima, and K. Shizume. 1986. Are hypothalamic GRF and SRIF involved in hypothyroidism-induced growth failure? Int. Congr. Neuroendocrinol., 1st, San Francisco, CA. (Abstr. 345)

30. Thorngren, K.-G., and L. I. Hansson. 1973. Effect of thyroxine and growth hormone on longitudinal bone growth in the hypophysectomized rat. Acta. Endocrinol. 74:24-40.

31. Minamitani, N., K. Chihara, J. Iwasaki, S. Matsukura, and T. Fujita 1982. Attenuation by hypocalcemia of pulsatile growth hormone secretion in conscious male rats. Neuroendocrinology. 35:405-410.

32. Frohman L. A., and T. R. Downs. 1986. Measurement of growth hormone-releasing factor. Methods Enzymol. 124:371-389.

33. Miyakawa, M., N. Hizuka, K. Takano, I. Tanaka, R. Horikawa, N. Honda, and K. Shizume. 1986. Radioimmunoassay for insulin-like growth factor I (IGF-I) using biosynthetic IGF-I. Endocrinol. Jpn. 33:795-801.

34. Bowsher, R. R., W.-H. Lee, J. M. Apathy, P. J. O'Brien, A. L. Ferguson, and D. P. Henry. 1991. Measurement of insulin-like growth factor-II in physiological fluids and tissues. I. An improved extraction procedure and radioimmunoassay for human and rat fluids. Endocrinology. 128:805-814.

35. Abelenda, M., and M. L. Puerta. 1991. Relationship among food intake, thyroid status and chronic cold-exposure in the rat. Horm. Metab. Res. 23:90-91.

36. Bruno, J. F., D. Olchovsky, J. D. White, J. W. Leidy, J. Song, and M. Berelowitz. Influence of food deprivation in the rat on hypothalamic expression of growth hormone-releasing factor and somatostatin. Endocrinology. 127:21112116.

37. DeFesi, C. R., H. S. Astier, and M. I. Surks. 1979. Kinetics of thyrotrophs and somatotrophs during development of hypothyroidism and L-triiodothyronine treatment of hypothyroid rats. Endocrinology. 104:1172-1180.
38. Dieguez, C., S. M. Foord, J. R. Peters, R. Hall, and M. F. Scanlon. 1985. The effects of thyroid hormone deprivation in vivo and in vitro on growth hormone $(\mathrm{GH})$ responses to human pancreatic (tumor) $\mathrm{GH}$-releasing factor $(1-40)$ by dispersed rat anterior pituitary cells. Endocrinology. 116:1066-1070.

39. Root, J. L., G. E. Duckett, M. Sweetland, J. A. Strzelecki, and A. W. Root. 1985. Hypothyroidism blunts the growth hormone $(\mathrm{GH})$ releasing effect of human pancreatic $\mathrm{GH}$ releasing factor in the adult male rat in vivo and in vitro. Endocrinology. 116:1703-1706.

40. Williams, T., H. Maxon, M. O. Thorner, and L. A. Frohman. 1985. Blunted growth hormone (GH) response to $\mathrm{GH}$-releasing hormone in hypothyroidism resolves in the euthyroid state. J. Clin. Endocrinol. Metab. 61:454-456.

41. Wehrenberg, W. B. 1986. The role of growth hormone-releasing factor and somatostatin on somatic growth in rats. Endocrinology. 118:489-494.

42. Lumpkin, M. D., S. E. Mulroney, and A. Haramati. 1989. Inhibition of pulsatile growth hormone $(\mathrm{GH})$ secretion and somatic growth in immature rats with a synthetic GH-releasing factor antagonist. Endocrinology. 124:1154-1159.

43. Lumpkin, M. D., and J. K. McDonald. 1989. Blockade of growth hormone-releasing factor (GRF) activity in the pituitary and hypothalamus of the conscious rat with a peptidic GRF antagonist. Endocrinology. 124:1522-1531.

44. De Gennaro, V., S. G. Cella, M. Bassetti, R. Rizzi, D. Cocchi, and E. E. Muller. 1988. Impaired growth hormone secretion in neonatal hypothyroid rats: hypothalamic versus pituitary component. Proc. Soc. Exp. Biol. Med. 187:99106.

45. Pascual-Leone, A. M., M. D. Garcia, F. Hervas, and G. Morreale de Escober. 1976. Decreased pituitary growth hormone content in rats treated neonatally with high doses of L-thyroxine. Horm. Metab. Res. 8:215-217.

46. Coulombe, P., J. Ruel, and J. H. Dussault. 1980. Effects of neonatal hypoand hyperthyroidism on pituitary growth hormone content in the rat. Endocrinology. 107:2027-2033.

47. Finkelstein, J. W., R. M. Boyar, and L. Hellman. 1974. Growth hormone secretion in hyperthyroidism. J. Clin. Endocrinol. Metab. 38:634-637.

48. Clark, R. G., and I. C. A. F. Robinson. 1985. Growth induced by pulsatile infusion of an amidated fragment of human growth hormone releasing factor in normal and GHRF-deficient rats. Nature (Lond.). 314:281-283.

49. Root, A. W., D. Shulman, J. Root, and F. Diamond. 1986. The interrelationships of thyroid and growth hormones: effect of growth hormone releasing hormone in hypo- and hyperthyroid male rats. Acta. Endocrinol. 113(Suppl. 279):367-375.

50. Wakabayashi, I., Y. Tonegawa, T. Ihara, M. Hattori, T. Shibasaki, and N. Ling. 1985. Plasma growth hormone response to human growth hormone releasing factor in rats administered with chlorpromazine and antiserum against somatostatin: effects of hypo- and hyperthyroidism. Neuroendocrinology. 41:306311

51. Berelowitz, M., K. Maeda, S. Harris, and L. A. Frohman. 1980. The effect of alterations in the pituitary-thyroid axis on hypothalamic content and in vitro release of somatostatin-like immunoreactivity. Endocrinology. 107:24-29.

52. Daughaday, W. H., and P. Rotwein. 1989. Insulin-like growth factors I and II. Peptide, messenger ribonucleic acid and gene structures, serum, and tissue concentrations. Endocr. Rev. 10:68-91.

53. Burstein, P. J., B. Draznin, C. J. Johnson, and D. S. Schalch. 1979. The effect of hypothyroidism on growth, serum growth hormone, the growth hormone-dependent somatomedin, insulin-like growth factor, and its carrier protein in rats. Endocrinology. 104:1107-1111.

54. Chernausek, S. D., L. E. Underwood, and J. J. Van Wyk. 1982. Influence of hypothyroidism on growth hormone binding by rat liver. Endocrinology. 111:1534-1538.

55. Lewinson, D., Z. Harel, P. Shenzer, M. Silbermann, and Z. Hochberg. 1989. Effect of thyroid hormone and growth hormone on recovery from hypothyroidism of epiphyseal growth plate cartilage and its adjacent bone. Endocrinology. 124:937-945.

56. Crantz, F. R., and Larsen, P. R. 1980. Rapid thyroxine to 3,5,3'triiodothyronine conversion and nuclear $3,5,3^{\prime}$-triiodothyronine binding in rat cerebral cortex and cerebellum. J. Clin. Invest. 65:935-938.

57. Oppenheimer, J. H. 1979. Thyroid hormone action at the cellular level. Science (Wash. DC). 203:971-979.

58. Riskind, P. N., J. M. Kolodny, and P. R. Larsen. 1987. The regional hypothalamic distribution of type II 5 '-monodeiodinase in euthyroid and hypothyroid rats. Brain Res. 420:194-198.

59. Bloch, B., P. Brazeau, N. Ling, P. Bohlen, F. Esch, W. B. Wehrenberg, R. Benoit, F. Bloom, and R. Guillemin. 1983. Immunohistochemical detection of growth hormone-releasing factor in brain. Nature (Lond.). 301:607-608.

60. Bloch, B., R. C. Gaillard, P. Brazeau, H. D. Lin, and N. Ling. 1984. Topographical and ontogenic study of the neurons producing growth hormonereleasing factor in human hypothalamus. Regul. Pept. 8:21-31.

61. Jones, P. M., J. M. Burrin, M. A. Ghatei, D. J. O'Halloran, S. Legon, and S. R. Bloom. 1990. The influence of thyroid hormone status on the hypothalamohypophyseal growth hormone axis. Endocrinology. 126:1374-1379. 